\title{
Effects of opioids on immunologic parameters that are relevant to anti-tumour immune potential in patients with cancer: a systematic literature review
}

\author{
J W Boland ${ }^{*}, 1, \mathrm{~K} \mathrm{McWilliams}^{2}$, S H Ahmedzai ${ }^{3}$ and A G Pockley ${ }^{4}$ \\ ${ }^{1}$ Hull York Medical School, University of Hull, Hull HU6 7RX, UK; ${ }^{2}$ Palliative Medicine Research Department, Beatson Oncology \\ Centre, Glasgow G11 OYN, UK; ${ }^{3}$ Department of Oncology, The Medical School, University of Sheffield, Sheffield S10 2RX, UK and \\ ${ }^{4}$ John van Geest Cancer Research Centre, Nottingham Trent University, Nottingham NG11 8NS, UK
}

Background: The immune system has a central role in controlling cancer, and factors that influence protective antitumour immunity could therefore have a significant impact on the course of malignant disease. Opioids are essential for the management of cancer pain, and preclinical studies indicate that opioids have the potential to influence these tumour immune surveillance mechanisms. The aim of this systematic literature review is to evaluate the clinical effects of opioids on the immune system of patients with cancer.

Methods: A systematic search of Ovid MEDLINE (PubMed) and Embase, Cochrane database and Web of Knowledge for clinical studies, which evaluated the effects of opioids on the immune system in patients with cancer, was performed.

Results: Five human studies, which have assessed the effects of opioids on the immune system in patients with cancer, were identified. Although all of these evaluated the effect of morphine on immunologic end points in patients with cancer, none measured the clinical effects.

Conclusions: Evidence from preclinical, healthy volunteer and surgical models suggests that different opioids variably influence protective anti-tumour immunity; however, actual data derived from cancer populations are inconclusive and definitive recommendations cannot be made. Appropriately designed and powered studies assessing clinical outcomes of opioid use in people with cancer are therefore required to inform oncologists and others involved in cancer care about the rational use of opioids in this patient group.

The innate and adaptive immune systems provide crucial protection against pathogenic organisms and cancer (Gaspani et al, 2002; Shavit et al, 2004; Nüssler et al, 2007). Cancer immunosurveillance involves natural killer (NK) cells that have an inherent (innate) capacity to recognise and kill tumours via cell surface molecules (Table 1), the secretion of immunoregulatory cytokines and the actions of white blood cell (lymphocyte) subsets, which control and regulate anti-tumour immunity ( $\mathrm{T}$ 'helper' or
$\mathrm{CD} 4{ }^{+} \mathrm{T}$ cells) or recognise and kill transformed cells ('cytotoxic' $\mathrm{T}$ or $\mathrm{CD}^{+}{ }^{+} \mathrm{T}$ cells) (Table 1) (Foulds et al, 2013).

The importance of immunosurveillance in the context of cancer has been illustrated by a number of findings. High NK cell cytotoxicity and high concentrations of cytotoxic $\mathrm{T}$ cells are associated with a reduced progression of disease and better survival in patients with colorectal cancer (Nüssler et al, 2007; Pages et al, 2009). In contrast, rodent studies using the MADB106 


\begin{tabular}{|c|c|c|c|c|}
\hline Cell & Role & Activators & Mechanism of activity & Arm \\
\hline Dendritic cell & Antigen presentation & $\begin{array}{l}\text { Multiple, including bacterial } \\
\text { products and cytokines }\end{array}$ & $\begin{array}{l}\text { Presentation of antigenic peptides in the context of MHC } \\
\text { class I and II molecules and the delivery of essential } \\
\text { costimulatory molecules }\end{array}$ & Innate \\
\hline Natural killer cell & $\begin{array}{l}\text { Anti-tumour } \\
\text { Anti-viral }\end{array}$ & $\begin{array}{l}\text { Multiple, including the lack of } \\
\text { MHC class I expression }\end{array}$ & Release of cytotoxic molecules (granzymes, perforin) & Innate \\
\hline Neutrophil & Anti-bacterial/-fungal & Opsonisation & Phagocytosis and oxidative burst & Innate \\
\hline $\begin{array}{l}\text { Monocyte-macrophage } \\
\text { lineage }\end{array}$ & Anti-bacterial/-fungal & $\begin{array}{l}\text { Opsonisation } \\
\text { Antigen presentation }\end{array}$ & Phagocytosis and oxidative burst & Innate \\
\hline $\mathrm{CD}^{+}{ }^{+} \mathrm{T}$ cell & $\begin{array}{l}\text { Immune coordination/ } \\
\text { regulation }\end{array}$ & $\begin{array}{l}\text { Antigenic peptides presented by } \\
\text { MHC class II plus essential } \\
\text { costimulatory molecules }\end{array}$ & Regulating the activity of other immune cells & Adaptive \\
\hline $\mathrm{CD}^{+} \mathrm{T}$ cell & Cytotoxicity & $\begin{array}{l}\text { Antigenic peptides presented by } \\
\text { MHC class I }\end{array}$ & $\begin{array}{l}\text { Induction of apoptosis by (i) release of cytotoxins } \\
\text { (perforin, granulysin, granzymes), (ii) direct cell-cell } \\
\text { contact, by upregulating surface Fas ligand }\end{array}$ & Adaptive \\
\hline B cell & Antibody production & $\begin{array}{l}\text { Antigens binding to surface } \\
\text { immunoglobulin with help from } \\
\mathrm{CD} 4^{+} \mathrm{T} \text { cells }\end{array}$ & Antibody production & Adaptive \\
\hline
\end{tabular}

(mammary adenocarcinoma) cell line have shown that tumour burden can increase if NK cell cytotoxicity is reduced (Gaspani et al, 2002; Shavit et al, 2004). Furthermore, the incidence of secondary cancers is higher in patients who have had chemotherapy for a primary cancer (Morton et al, 2013). The effect of immune system impairment can also be selective, as there is a higher incidence of non-Hodgkin's lymphoma, lip cancer and melanoma in transplant recipients on immunosuppressive treatment, whereas the incidence of leukaemia, lung, kidney and urinary tract cancers remained the same (Van Leeuwen et al, 2010).

The central role that the immune system has in protecting against cancer means that any factors that influence protective anti-tumour immunity are likely to have a profound impact on the course of disease. Although opioids are essential for the management of cancer pain, numerous in vitro, animal and volunteer models have reported opioids to have a number of immunoregulatory effects. These are dependent on the opioid being tested, the component of the immune system that is being influenced, the administration schedule and also the experimental model (Van Der Laan et al, 1996; West et al, 1997; Martucci et al, 2004). Given the evidence that opioids have the capacity to influence anti-tumour immunity, it is important to better understand the potential clinical impact of opioid usage in this context.

Although the immune effects of opioids in patients with cancer have been reviewed previously (Budd, 2006; Pergolizzi et al, 2008; Sacerdote, 2008), there has been no systematic review of the literature assessing the effects of opioids on anti-tumour immune potential in patients with cancer and how these effects could influence the clinical management. The immunologic consequences of opioids that are administered to patients with chronic cancer pain over a period of several months are likely to be very different to those that are induced by the relatively short treatments that are administered to healthy volunteers or patients post-surgery, because of the differing immunologic phenotypes of these groups (Snyder and Greenberg, 2010; Colvin et al, 2012; Heaney and Buggy, 2012; Foulds et al, 2013; Galizia et al, 2013). We therefore conducted a new systematic review of the literature relating to the effects of a broad range of therapeutic opioids on immunologic parameters that are relevant to protective anti-cancer immunity in non-surgical clinical studies.
It is becoming apparent that an individualised approach to cancer pain treatment is essential, as the analgesic properties and side effects of opioids exhibit great interindividual variability (Ahmedzai, 2013), as do their influence on immune cell function (Thomas et al, 1995; Jacobs et al, 1999). Furthermore, even if opioids were to have immunomodulatory effects in patients, this would only be of clinical interest and relevant to prescribers if these significantly influenced tumour growth, metastasis, infection and/ or other clinical outcomes.

We have identified five studies that evaluated the effect of opioids on immune function in patients with cancer. However, the literature indicates that only the effect of morphine has been evaluated, and none of the studies have reported on relevant clinical end points.

\section{MATERIALS AND METHODS}

Search strategy and selection criteria. The aim of this review was to identify all relevant non-surgical clinical studies that have evaluated the effects of opioids on the immune system in patients with cancer. On 8 November 2013, the electronic databases Ovid MEDLINE (PubMed) and Embase (Ovid MEDLINE(R) 1946 to Present and Ovid MEDLINE In-Process and Other Non-Indexed Citations, and Embase 1974 to 2013 Week 29), Cochrane database and Web of Knowledge were searched using the terms and dates listed below. These were devised to be inclusive of all potentially relevant studies and have been extended to include terms relating to other conditions that are mapped to Medical Subject Heading $(\mathrm{MeSH})$ terms as well as searching for these terms as text word searches to increase the search sensitivity. To search for opioids, the search terms used were: opioid OR opiate OR morphine OR codeine OR buprenorphine OR methadone OR tramadol OR tapentadol OR oxycodone OR heroin OR fentanyl OR hydromorphone OR oxymorphone. These were combined with a search for cancer OR neoplasm and immunity: including immune* OR NK cell OR T cell. The limits were English language; clinical trial (any); adults; humans; all adult (MEDLINE) from 1974 to 2013. All titles and abstracts were reviewed to assess their relevance for inclusion. The results of these searches are shown in the PRISMA Flow Diagram (Figure 1; Moher et al, 2009). 


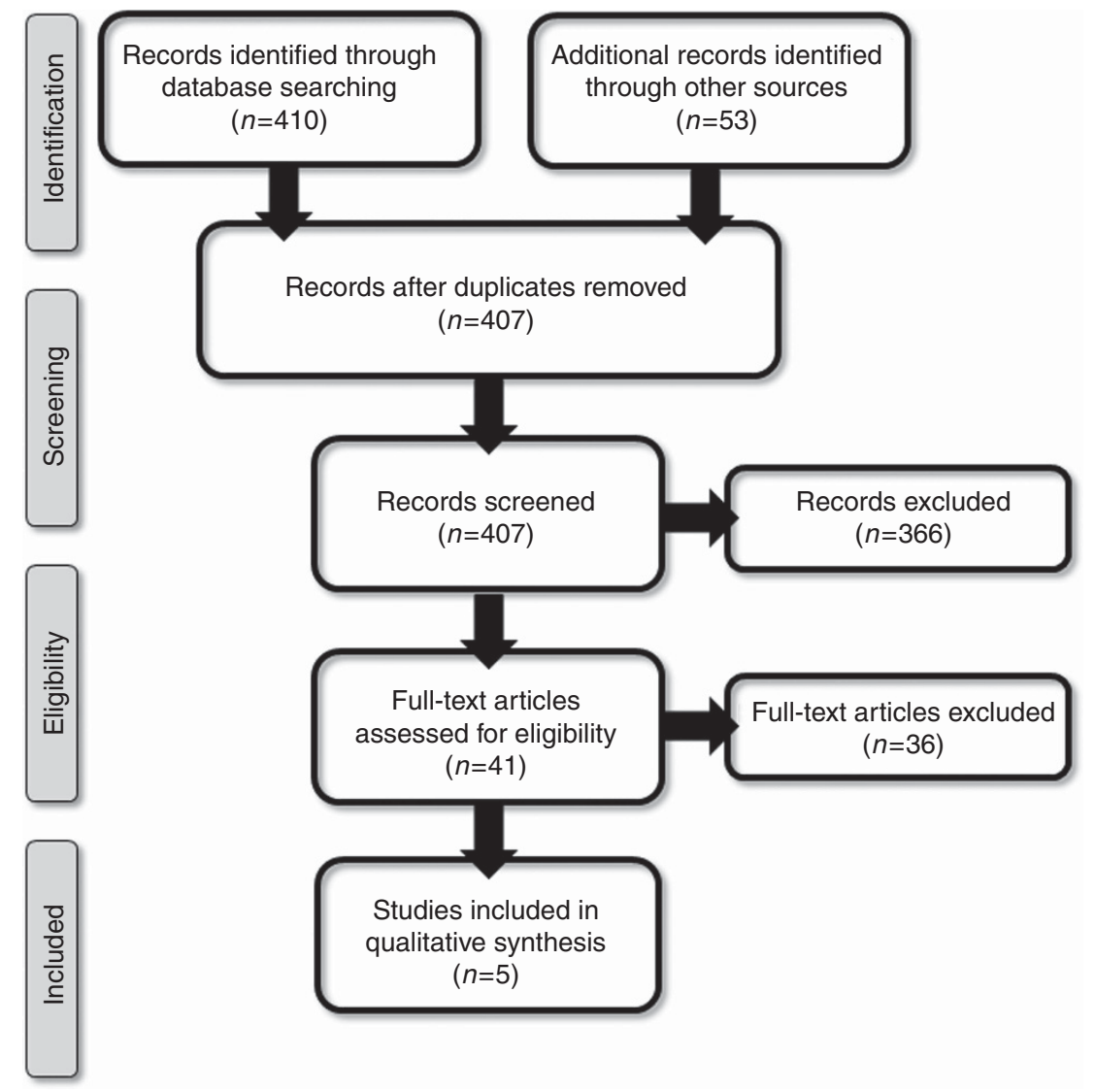

Figure 1. PRISMA flow diagram.

In addition to the electronic search, reference lists from identified reviews and key publications were manually searched. Articles were also identified through searches of the authors' own files, previous reviews on opioid-induced immunosuppression and outputs from prominent researchers in the field. Only papers published as full-text articles in English were reviewed. Surgical studies, patients undergoing cancer surgery, healthy volunteer studies and animal studies were excluded from this systematic review, as these groups have different opioid usage, immune system activation and receptor expression compared with patients on long-term opioids for cancer pain (Snyder and Greenberg, 2010; Colvin et al, 2012; Heaney and Buggy, 2012; Foulds et al, 2013; Galizia et al, 2013). Patients undergoing surgery are also exposed to a range of drugs during the operation, which potentially impact on immune function (Colvin et al, 2012; Heaney and Buggy, 2012). Furthermore, the effect of opioids in patients undergoing cancer surgery has been reviewed elsewhere (Colvin et al, 2012; Heaney and Buggy, 2012). As the data are only relevant if opioids have significant clinical effects, we specifically looked for articles that assessed clinical effects.

Two authors (JB and KM) undertook independent electronic literature searches and reviewed all titles and abstracts. Full papers were retrieved for those fulfilling the criteria, and also for those publications for which the ability to assess their eligibility could not be assessed on the basis of the titles and abstracts alone. Two review authors (JB and $\mathrm{KM}$ ) then assessed the full text of all potentially relevant studies. Disagreement at all stages was resolved by consensus and with recourse to a third review author (AGP).

Data extraction, assessment and analysis. JB and KM independently extracted data regarding study design and results and assessed their quality. Data extracted were the type of study, study setting, study population (cancer type, stage, treatment) opioid used, dose and clinical outcome measures (e.g. survival). The methodologic quality of each study was independently assessed by JB and KM using Quality Assessment of Studies of Diagnostic Accuracy included in Systematic Reviews (QUADAS-2) (Whiting et al, 2011).

\section{RESULTS}

This systematic review of the effects of therapeutic opioids on immune function in patients with cancer identified five studies that were eligible for inclusion (Table 2). All were found to be prospective observational studies and no randomised controlled trials have been undertaken. These clinical studies have focused on the effects of opioids on markers of immune function, rather than on relevant clinical outcomes. All studies examined the effects of morphine - no other opioids have been investigated.

The quality of studies was determined using a QUADAS-2 analysis (Whiting et al, 2011). Included studies had a low risk of bias (patient selection, index test and flow and timing) and an unclear risk of reference standard. The two studies by Provinciali et al $(1991,1996)$ had an unclear patient selection risk. All studies had a low risk for applicability concerns (patient selection, index test and reference standard).

Makimura et al (2011) attempted to find markers that could predict resistance to morphine treatment by examining the plasma concentrations of 26 cytokines before and after morphine treatment in 44 patients with metastatic cancer (Table 2). They observed interindividual variability in baseline plasma cytokine concentrations and found no significant changes in the levels of 
Table 2. Summary of the effect of opioids on immune function in patients with cancer

\begin{tabular}{|c|c|c|c|c|c|}
\hline $\begin{array}{l}\text { Author } \\
\text { (year) }\end{array}$ & Research question & $\begin{array}{l}\text { Patient } \\
\text { population }\end{array}$ & $\begin{array}{l}\text { Study design and method } \\
\text { of recruitment }\end{array}$ & $\begin{array}{l}\text { Interventions (opioid and } \\
\text { doses) and comparator }\end{array}$ & $\begin{array}{l}\text { Assoc. between opioid } \\
\text { and immune function }\end{array}$ \\
\hline $\begin{array}{l}\text { Makimura } \\
\text { et al (2011) }\end{array}$ & $\begin{array}{l}\text { Are plasma cytokine } \\
\text { levels potential } \\
\text { biomarkers for } \\
\text { predicting resistance to } \\
\text { morphine treatment in } \\
\text { opioid-naive cancer } \\
\text { patients? }\end{array}$ & $\begin{array}{l}4 \text { Patients } \\
\text { Age } 69(40-85) \\
\text { years } \\
50 \% \text { Men } \\
93 \% \text { Metastatic } \\
\text { cancer } \\
\text { PS status } 1(20 \%), \\
2(55 \%), 3(23 \%), \\
4(2 \%)\end{array}$ & $\begin{array}{l}\text { Prospective observational study } \\
\text { Cytokines measured at baseline } \\
\text { and compared with samples after } \\
8 \text { days of opioid treatment } \\
\text { Morphine titrated as per a } \\
\text { standardised protocol (dose not } \\
\text { specified) }\end{array}$ & $\begin{array}{l}\text { Morphine - doses not specified } \\
\text { Patients acted as own controls, } \\
\text { baseline samples compared with } \\
\text { day } 8\end{array}$ & $\begin{array}{l}\text { None (except MIP-1a level } \\
\text { decreased }(P=0.03 \text { ) but multiple } \\
\text { comparisons) (baseline: } \\
7.2 \pm 19.3 \mathrm{pg} \mathrm{ml}^{-1} \text { vs day } 8 \\
\left.2.3 \pm 7.4 \mathrm{pg} / \mathrm{ml}^{-1}\right) \\
\text { Plasma IL-12 (p40) level } \\
\text { decreased nonsignificantly } \\
(P=0.07) \text { (baseline: } \\
7.0 \pm 17.4 \mathrm{pg} \mathrm{ml}^{-1} \text {, day } 8: \\
2.7 \pm 7.6 \mathrm{pg} \mathrm{ml}^{-1} \text { ) } \\
\text { No clinical end points measured }\end{array}$ \\
\hline $\begin{array}{l}\text { Hashiguchi } \\
\text { et al (2005) }\end{array}$ & $\begin{array}{l}\text { Do morphine and its } \\
\text { metabolites modulate } \\
\text { immune function in } \\
\text { advanced cancer } \\
\text { patients? }\end{array}$ & $\begin{array}{l}\text { 14 Patients } \\
\text { Age 28-76 years } \\
\text { 53\% Men } \\
\text { Mixed-stage IV } \\
\text { cancers } \\
\text { (including breast, } \\
\text { tongue, } \\
\text { sarcomas) } \\
\text { PS - not } \\
\text { documented } \\
\text { Group 1: } 6 \\
\text { patients, opioid } \\
\text { naive } \\
\text { Group 2: } 8 \\
\text { patients on } \\
\text { morphine for } 1 \\
\text { month }\end{array}$ & $\begin{array}{l}\text { Prospective observational study } \\
\text { Bloods at enrollment (phase 1), } 1 \\
\text { week after starting or changing } \\
\text { morphine dose/route (phase 2) } \\
\text { and } 2 \text { weeks after phase } 2 \text { (phase } \\
\text { 3). Phase } 2 \text { was between } 10 \text { and } \\
21 \text { days after phase } 1 \\
\text { Limitations - } 1 \text { patient in group } 2 \\
\text { excluded from phase } 2 \text { analysis; } 2 \\
\text { in group } 1 \text {, and } 4 \text { in group } 2 \\
\text { excluded from phase } 3 \text { analysis } \\
\text { due to deterioration }\end{array}$ & $\begin{array}{l}\text { Group 1, final morphine dose } \\
20-30 \mathrm{mg} \text { (routes: oral, } \\
\text { intravenous) group 2: starting } \\
\text { morphine dose } 40-120 \mathrm{mg} \text { (oral, } 1 \\
\text { rectal); final morphine dose 20- } \\
240 \mathrm{mg} \text { (routes: oral, intravenous, } \\
\text { subcutaneous, rectal) } \\
\text { Patients acted as own controls }\end{array}$ & $\begin{array}{l}\text { Negative correlation in Group } 1 \\
\text { between morphine, M3G and } \\
\text { M6G and immunoglobulin's and } \\
\text { PHA-induced lymphocyte } \\
\text { proliferation but not NK cell } \\
\text { activity or CD4/CD8 ratio } \\
\text { Poor correlation for all } \\
\text { immunologic markers in Group } 2 \\
\text { No clinical end points measured }\end{array}$ \\
\hline $\begin{array}{l}\text { Provinciali } \\
\text { et al (1991) }\end{array}$ & $\begin{array}{l}\text { How does morphine } \\
\text { affect NK and LAK cell } \\
\text { activity in neoplastic } \\
\text { patients? }\end{array}$ & $\begin{array}{l}20 \text { Patients with } \\
\text { cancers of } \\
\text { different origins } \\
\text { (including breast, } \\
\text { lung, ovarian and } \\
\text { prostate) } \\
\text { Age, gender, } \\
\text { cancer stage, and } \\
\text { PS status not } \\
\text { reported }\end{array}$ & $\begin{array}{l}\text { Prospective observational study } \\
\text { Blood analysed } 1 \text { month after } \\
\text { starting treatment and compared } \\
\text { with healthy volunteers } \\
\text { (transfusion centre) } \\
\text { Limitations - no baseline analysis }\end{array}$ & $\begin{array}{l}N=9 \text { p.o. morphine } \pm 30 \mathrm{mg} \text { per } \\
\text { day } \\
N=6 \text { i.t. morphine patients } \\
4 \pm 1.5 \mathrm{mg} \text { per day } \\
N=5 \text { opioid-naive patients } \\
\text { Three patients acted as own } \\
\text { controls from p.o. morphine to } \\
\text { subsequent i.t. treatment } \\
\text { Blood from healthy subjects } \\
\text { provided by transfusion centre }\end{array}$ & $\begin{array}{l}\text { Sig reduced NK cell activity } \\
(P<0.05) \\
\text { NK cell activity reduced further } \\
\text { with i.t. than p.o. } \\
\text { LAK cell activity significantly } \\
\text { increased } \\
\text { LAK cell activity higher in p.o. } \\
\text { than i.t. }(P<0.005) \\
\text { No clinical measurements }\end{array}$ \\
\hline $\begin{array}{l}\text { Provinciali } \\
\text { et al (1996) }\end{array}$ & $\begin{array}{l}\text { How does short- or long- } \\
\text { term morphine } \\
\text { administration affect NK/ } \\
\text { LAK activities? }\end{array}$ & $\begin{array}{l}18 \text { Patients } \\
\text { (breast, lung, } \\
\text { ovary, prostate, } \\
\text { bladder, colon, } \\
\text { larynx, stomach } \\
\text { and kidney } \\
\text { cancer) } \\
\text { Age, gender, } \\
\text { cancer stage and } \\
\text { PS status not } \\
\text { reported } \\
10 \text { patients } \\
\text { treated with } \\
\text { morphine } \\
8 \text { patients had no } \\
\text { opioids }\end{array}$ & $\begin{array}{l}\text { Prospective interventional study } \\
\text { Short term }-9 \text { patients treated } \\
\text { with i.v. } 10 \mathrm{mg} \text { morphine ( } 4 \\
\text { pretreated with } 5 \mathrm{mg} \mathrm{p.o.} \\
\text { bromocriptine). Blood checked at } \\
\text { baseline and after } 30 \mathrm{~min} \\
\text { Long-term p.o. morphine } \\
(90 \pm 30 \mathrm{mg} \text { ) for } 1 \text { month } \\
\text { Limitations }-8 \text { controls low/no } \\
\text { pain, } 10 \text { active patients had high } \\
\text { levels of pain }\end{array}$ & $\begin{array}{l}\text { Morphine: } 10 \mathrm{mg} \text { i.v. in short-term } \\
\text { study } 90 \pm 30 \mathrm{mg} \text { per day p.o. for } \\
1 \text { month in long term study } \\
N=8 \text { opioid naive cancer patients } \\
\text { as controls }\end{array}$ & 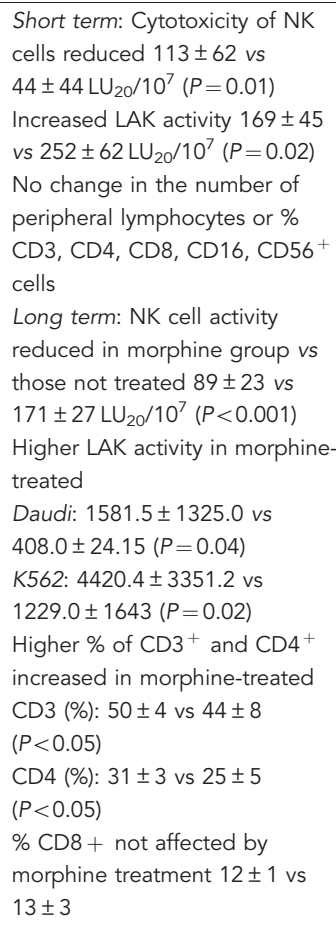 \\
\hline
\end{tabular}




\section{Table 2. (Continued)}

\begin{tabular}{|c|c|c|c|c|c|}
\hline $\begin{array}{l}\text { Author } \\
\text { (year) }\end{array}$ & Research question & $\begin{array}{l}\text { Patient } \\
\text { population }\end{array}$ & $\begin{array}{l}\text { Study design and method } \\
\text { of recruitment }\end{array}$ & $\begin{array}{l}\text { Interventions (opioid and } \\
\text { doses) and comparator }\end{array}$ & $\begin{array}{l}\text { Assoc. between opioid } \\
\text { and immune function }\end{array}$ \\
\hline & & & & & $\begin{array}{l}\text { Decrease } \% \mathrm{CD} 16^{+} \text {cells in } \\
\text { morphine treatment } 13 \pm 3 \text { vs } \\
20 \pm 6(P<0.05) \\
\text { No clinical end points }\end{array}$ \\
\hline $\begin{array}{l}\text { Palm et al } \\
\text { (1998) }\end{array}$ & $\begin{array}{l}\text { Does prolonged oral } \\
\text { treatment with sustained } \\
\text { release morphine tablet } \\
\text { influence immune } \\
\text { function? }\end{array}$ & $\begin{array}{l}10 \text { Patients ( } 3 \\
\text { advanced cancer } \\
\text { related pain; } 7 \\
\text { non-malignant } \\
\text { pain) } \\
\text { Age } 51.5 \text { (37-65) } \\
\text { years } \\
60 \% \text { Men } \\
\text { PS not reported } \\
\text { Eight age- and } \\
\text { sex-matched } \\
\text { healthy controls }\end{array}$ & $\begin{array}{l}\text { Prospective observational study } \\
\text { Blood samples before initiation of } \\
\text { morphine treatment and after 1, } 4 \\
\text { and } 12 \text { weeks }\end{array}$ & $\begin{array}{l}\text { Morphine dose } 30-240 \text { mg per } \\
\text { day } \\
\text { Patients acted as own controls } \\
\text { from baseline measurements and } \\
\text { were also compared with age- and } \\
\text { sex-matched healthy controls }\end{array}$ & $\begin{array}{l}\text { Total lymphocyte counts, } \\
\text { lymphocyte sub-populations, } \\
\text { PHA-induced proliferation of } \\
\text { PMC did not differ between } \\
\text { patients and controls at baseline } \\
\text { or during } 12 \text { week study period } \\
\text { PMC synthesis of IL- } 2 \text { increased } \\
\text { five-fold after } 4 \text { weeks morphine } \\
\text { treatment ( } P<0.05 \text { ) } \\
\text { IgM production from PMW cells } \\
\text { no longer possible after } 4 \text { weeks } \\
\text { morphine treatment } \\
\text { Impairment of spontaneous and } \\
\text { PWM-stimulated IgG production } \\
\text { No difference in IgG or IgM } \\
\text { between patients and controls at } \\
\text { baseline or during treatment } \\
\text { No clinical end points }\end{array}$ \\
\hline
\end{tabular}

any cytokine (including interleukin-2 (IL-2)) after 8 days of treatment with morphine in previously opioid naive patients. This contrasts with the study by Palm et al (1998), which showed that the synthesis and secretion of IL-2 by lymphocytes increased significantly after 4 weeks of morphine treatment in 10 patients with chronic pain (including three with cancer). No clinical end points, for example, cancer progression- or disease-free survival were evaluated in either study (Palm et al, 1998, Makimura et al, 2011). This may suggest that the acute effects of opioids (over days) on the immune system differ from those that are induced following chronic exposure (over weeks).

The possibility that the immunologic consequences of opioids (morphine) depends on the nature of the exposure has been confirmed in a study of 15 patients with advanced cancer by Hashiguchi et al (2005) (Table 2), which reported that the impact of opioids on immune function might correlate with the duration of opioid administration. They found a negative correlation between the levels of morphine metabolites and circulating immunoglobulin levels and the in vitro proliferation of peripheral blood lymphocytes in response to phytohaemagglutin (a nonspecific activator of $\mathrm{T}$ cells) in patients who had just commenced on morphine. In contrast, no such effects were observed in patients who had been on morphine for over 1 month. Once again, no clinical parameters were measured.

Patients with a variety of cancers (including breast, lung, ovarian and prostate) on oral or intrathecal morphine have been reported to exhibit a lower NK cell activity and increased lymphokine-activated killer (LAK) cell activity than untreated or healthy controls (Table 2; Provinciali et al, 1991). The observation that intrathecally delivered morphine had a more profound effect than oral morphine suggests an important role for a centrally mediated effect. However, only a very small number of patients was studied and no clinical correlates were investigated (Provinciali et al, 1991). In a subsequent study, Provinciali et al (1996) determined the short-term immune effects (at $30 \mathrm{~min}$ ) after a single $10 \mathrm{mg}$ intravenous dose of morphine and the long-term effects after 1 month of oral morphine $(90 \pm 30 \mathrm{mg}$ per day) on NK and LAK cell cytotoxicity in 18 patients with cancer (including breast, lung, ovary and prostate). These cytotoxicity responses were compared with baseline measurements, and those that were present before opioid treatment in the short-term experiments and in cancer patients not on opioids in the long-term study. This study demonstrated that both acute and chronic morphine administration reduced NK cell activity and increased LAK activity. Chronic morphine administration has also been shown to increase the proportion of $\mathrm{CD}^{+}$and $\mathrm{CD}^{+}{ }^{+} \mathrm{T}$ cells in peripheral blood mononuclear cell preparations, whereas the prevalence of $\mathrm{CD} 8{ }^{+} \mathrm{T}$ cells is unaffected and the proportion of $\mathrm{CD}_{16}{ }^{+}$lymphocytes is reduced. CD16 is a member of the $\mathrm{Fc}$ receptor family that is instrumental for the induction of antibodydependent cellular cytotoxicity (ADCC). Antibody-dependent cellular cytotoxicity is a mechanism of cell-mediated immune defence and a decrease in the presence of such cells might therefore negatively impact on tumour surveillance. None of these parameters were affected during acute morphine administration (Provinciali et al, 1996). The number of patients in this study was also small, their cancers were different and once again no clinical measurements of tumour progression or survival were measured.

In summary, the studies included here suggest that the influence of morphine on immune potential could be dependent on whether it is administered acutely or chronically, the route of administration and also the immune parameters that are considered. These observations cannot be extrapolated to all opioids due to the heterogeneous physicochemical and pharmacologic properties of this broad class of drugs (Sacerdote et al, 1997; Keiser et al, 2009). Furthermore, the most important outcome - the clinical impact of these immune influences on cancer progression and patient survival - remains unexplored.

\section{DISCUSSION}

The management of pain is essential, as its immunosuppressive properties can influence cancer growth in animal models (Page et al, 2001; Gaspani et al, 2002; Page, 2003, 2005). Fears of precipitating serious toxicity and the risk of dependence and 
tolerance make clinicians commonly reluctant to prescribe opioids, even for patients with significant cancer-related pain (Pergolizzi et al, 2008; Breuer et al, 2011). This is leading to the greater use of non-pharmacologic methods of pain control such as the delivery of opioids intrathecally, rather than in the form of long-term systemic treatment. Radiation therapy and adjunctive treatments including bisphosphonates and RANK ligand antibodies can also reduce bone cancer pain, and vertebroplasty or balloon kyphoplasty offers good pain relief from vertebral metastases (Terpos et al, 2014). The possibility that morphine can directly influence proliferation, apoptosis and metastatic potential of cancer cells and increase tumour growth in animal models raises additional concerns that opioids might promote disease progression (Gaspani et al, 2002; Shavit et al, 2004; Afsharimani et al, 2011; Gach et al, 2011). Despite these alternatives and their potential benefits, opioids continue to be essential for the management of cancer pain. Indeed, it is possible that the immunosuppressive effects of pain can be reversed by certain opioids, as tramadol (but not morphine) can overcome the capacity of surgical stress to decrease NK cell activity and enhance tumour metastasis in preclinical models (Gaspani et al, 2002).

Immune cells express ORL1 when resting and the mu opioid receptor, which is considered to be critical for immune cells to respond directly to most commonly prescribed opioids, following activation (Williams et al, 2007; Borner et al, 2008). Opioid receptor activation triggers multiple downstream signalling events, which include decreasing cyclic adenosine monophosphate (cAMP), increasing nitric oxide and cyclic guanosine monophosphate levels, and the stimulation of phospholipase C, mitogen-activated protein kinase (MAPK) and protein kinase C (Kelly et al, 2008; Stefano et al, 2008). All of these interactions ultimately interfere with immune cell activation pathways, which involve cAMP and MAPK (Borner et al, 2008, 2009). Activated immune cells can produce several opioid peptides (such as $\beta$ endorphin) in addition to endogenous morphine that can bind to opioid receptors present on peripheral nerves to induce analgesia (Stein and Lang, 2009; Glattard et al, 2010). The presence of opioid receptors on activated lymphoid cells suggests that endogenous opioids released by such cells could also contribute to an inhibitory feedback loop (Borner et al, 2008). These potential effects are summarised in Figure 2.

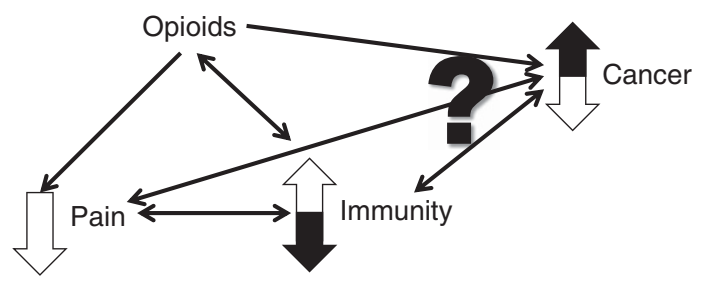

Figure 2. Quadrangulation of the effects of opioids on pain, immunity and cancer. Under normal circumstances opioids inhibit pain, which is itself immunosuppressive (Page et al, 2001; Page, 2003). Some opioids also have specific effects on immune function, either suppressive or stimulatory, and the balance of these opioid-mediated effects influences the progression of cancer (in animal models) (Gaspani et al, 2002). The immune system, via microglia and cytokines, influences the pain state (Hutchinson et al, 2008). Activated immune cells can also produce endogenous opioids, as well as morphine (Stein and Lang, 2009; Glattard et al, 2010). Cancer can also cause pain, by nociceptive, neuropathic and inflammatory mechanisms. There is a dynamic interaction of the immune system and cancer with immunoediting and immunosculpting (Reiman et al, 2007). Furthermore, there are nonimmune effects of opioids on cancer cells (Gach et al, 2011). All of these factors combine to create the net balance of cancer cell growth or destruction (Page, 2005). The white arrows indicate a beneficial effect on pain, immunity and cancer, and the solid arrows indicate a detrimental effect on immunity and cancer.
The immunoregulatory effects of morphine and some other opioids can also be elicited by direct effects on immune cells expressing non-opioid receptors such as Toll-like receptor 4 (TLR4) (Wang et al, 2002; Borner et al, 2008, 2009; Keiser et al, 2009; Hutchinson et al, 2010; Franchi et al, 2012). Opioids can also have indirect effects that manifest via centrally produced mediators such as immunosuppressive glucocorticoids that are released as a consequence of hypothalamic pituitary adrenal axis activation, and via effects on the sympathetic nervous system, which innervates lymphoid organs (Figure 3; Wang et al, 2002).

Studies in rats have reported that oral morphine can suppress T- and B-cell proliferation and NK cell activity (Van Der Laan et al, 1996; West et al, 1997). Conversely, rodent models have shown that tramadol, but not morphine, dose-dependently increases NK cell cytotoxicity. Furthermore, tramadol, but not morphine, reduces lung metastasis following the injection of MADB106 mammary tumour cells into rats (Gaspani et al, 2002). The capacity of tramadol to enhance immunity might be because of its coexisting intrinsic serotonergic effect (Sacerdote et al, 2000; Gaspani et al, 2002). In mice, a single subcutaneous dose of fentanyl, but not buprenorphine, decreases lymphoproliferation in response to the mitogen concanavalin $\mathrm{A}$, but has no effect on $\mathrm{NK}$ cell cytotoxicity (Martucci et al, 2004). A continuous infusion of fentanyl has been shown to decrease lymphoproliferation and NK cell cytotoxicity at $24 \mathrm{~h}$, with NK cell cytotoxicity normalising by day 3. However, tolerance to the effects on lymphoproliferation did not develop until day 7 in these studies (Martucci et al, 2004). Buprenorphine had no such effects. In a rodent surgical model, a

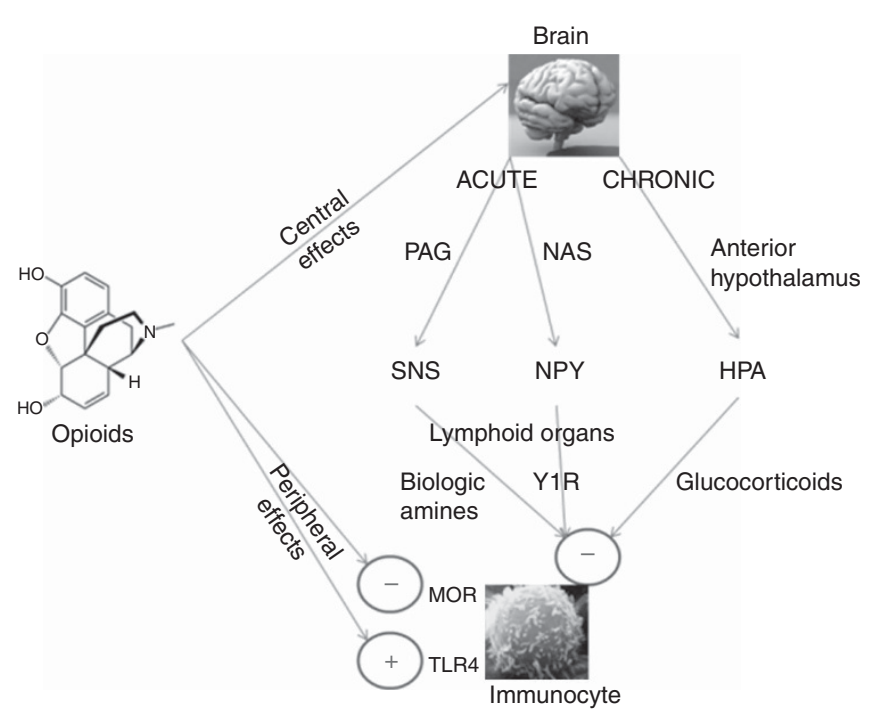

Figure 3. Peripheral and central mechanisms of opioid-induced immune suppression. Different opioids can have direct effects on immune cells, which express appropriate receptors such as mu-opioid receptors (MORs) and TLR4. They can also have immunosuppressive effects on specific immune cells via central mechanisms. Acute opioid administration enhances activity in the periaqueductal gray (PAG) matter, which activates the sympathetic nervous system (SNS). The SNS innervates lymphoid organs, such as the spleen, and this activation induces the release of biologic amines, which suppress splenic lymphocyte proliferation and natural killer (NK) cell cytotoxicity (Irwin et al, 1988; Fecho et al, 1996). Second, prolonged use of opioids increases hypothalamic pituitary adrenal (HPA) axis activity and glucocorticoid production, which decrease NK cell cytotoxicity (Fecho et al, 1996; Mellon and Bayer, 1998). Morphine can also act via $D_{1}$ dopamine receptors in the nucleus accumbens shell, increasing the release of neuropeptide $Y$ (NPY) and reducing splenic NK cell cytotoxicity in rodent models (Saurer et al, 2006). 
single dose of fentanyl increased suppression of NK cell activity and resulted in more lung metastasis following the injection of MADB106 tumour cells (Forget et al, 2010). Although NK cell cytotoxicity in healthy volunteers is suppressed by morphine (Yeager et al, 1995), fentanyl has been shown to increase the number of circulating NK cells and NK cell cytotoxicity (Jacobs et al, 1999; Yeager et al, 2002).

Although clinically relevant concentrations of morphine and methadone have been shown to inhibit cytotoxicity of NK cells from rats, monkeys and pigs (Molitor et al, 1992; Condevaux et al, 2001), such effects have not been seen in healthy volunteers, with in vitro studies indicating that clinically relevant concentrations of morphine, methadone, fentanyl and diamorphine do not influence NK or T cells (Yeager et al, 1992; House et al, 1995, Thomas et al, 1995; Jacobs et al, 1999; Boland et al, 2013).

The preclinical data indicate that tramadol might be potentially stimulating of the immune response (Gaspani et al, 2002) and buprenorphine to be immune neutral (Martucci et al, 2004), however until there are comparative studies with clinical end points, no one opioid can be strongly recommended over another in terms of their immune effects. Furthermore, cancers will have differential effects on the immune status and immune regulatory profiles and responses in one patient might not be broadly applicable to all.

\section{CONCLUSIONS}

All studies discussed in this systematic review were prospective and observational. They all used morphine and no study reported the effects on clinical end points. Although the studies included in this review add to the current body of knowledge of opioid effects on the immune system, these findings cannot currently be extrapolated to cancer patients on chronic opioids for pain owing to differences in immune cell activation and opioid receptor expression (Borner et al, 2008). As a consequence, there is currently insufficient evidence on which to base a more rational choice of opioids for optimising pain control without negatively impacting on the patient's essential protective immune function. It is therefore hoped that clinically derived data will provide better evidence in the future. In the meantime, judicious doses of opioids should continue to be used as part of a multimodal approach for the management of patients with cancer pain.

\section{AUTHOR CONTRIBUTIONS}

JB and KM undertook the literature search and contributed to study design, data collection and data analysis. JB provided the figures. AGP contributed to the study design. All authors were responsible for the writing and approval of the final report.

\section{CONFLICT OF INTEREST}

The authors declare no conflict of interest.

\section{REFERENCES}

Afsharimani B, Cabot P, Parat MO (2011) Morphine and tumor growth and metastasis. Cancer Metast Rev 30(2): 225-238.

Ahmedzai SH (2013) Personalized medicine - one size fits one: tailoring pain therapy to individuals' needs. J Pain Palliat Care Pharmacother 27: 83-85.

Boland JW, Foulds GA, Ahmedzai SH, Pockley AG (2013) A preliminary evaluation of the effects of opioids on innate and adaptive human in vitro immune function. BMJ Support Palliat Care; e-pub ahead of print 27 December 2013; doi:10.1136/bmjspcare-2013-000573.

Borner C, Kraus J, Bedini A, Schraven B, Hollt V (2008) T-cell receptor/ CD28-mediated activation of human $\mathrm{T}$ lymphocytes induces expression of functional mu-opioid receptors. Mol Pharmacol 74: 496-504.

Borner C, Warnick B, Smida M, Hartig R, Lindquist JA, Schraven B, Hollt V, Kraus J (2009) Mechanisms of opioid-mediated inhibition of human T cell receptor signaling. J Immunol 183: 882-889.

Breuer B, Fleishman SB, Cruciani RA, Portenoy RK (2011) Medical oncologists' attitudes and practice in cancer pain management: a national survey. J Clin Oncol 29: 4769-4775.

Budd K (2006) Pain management: is opioid immunosuppression a clinical problem? Biomed Pharmacother 60: 310-317.

Colvin LA, Fallon MT, Buggy DJ (2012) Cancer biology, analgesics, and anaesthetics: is there a link? Br J Anaesth 109: 140-143.

Condevaux F, Guichard J, Forichon A, Aujoulat M, Descotes J (2001) Compared effects of morphine and nickel chloride on NK cell activity in vitro in rats and monkeys. J Appl Toxicol 21: 431-434.

Fecho K, Maslonek KA, Dykstra LA, Lysle DT (1996) Evidence for sympathetic and adrenal involvement in the immunomodulatory effects of acute morphine treatment in rats. J Pharmacol Exp Ther 277: 633-645.

Forget P, Collet V, Lavand'homme P, De Kock M (2010) Does analgesia and condition influence immunity after surgery? Effects of fentanyl, ketamine and clonidine on natural killer activity at different ages. Eur J Anaesthesiol 27: 233-240.

Foulds GA, Radons J, Kreuzer M, Multhoff G, Pockley AG (2013) Influence of tumors on protective anti-tumor immunity and the effects of irradiation. Front Oncol 3: 1-17.

Franchi S, Moretti S, Castelli M, Lattuada D, Scavullo C, Panerai AE, Sacerdote P (2012) Mu opioid receptor activation modulates Toll like receptor 4 in murine macrophages. Brain Behav Immun 26: 480-488.

Gach K, Wyrebska A, Fichna J, Janecka A (2011) The role of morphine in regulation of cancer cell growth. Naunyn-Schmiedeberg's Archiv Pharmacol 384: 221-230.

Galizia G, Gemei M, Orditura M, Romano C, Zamboli A, Castellano P, Mabilia A, Auricchio A, De Vita F, Del Vecchio L, Lieto E (2013) Postoperative detection of circulating tumor cells predicts tumor recurrence in colorectal cancer patients. J Gastrointest Surg 17: 1809-1818. Gaspani L, Bianchi M, Limiroli E, Panerai AE, Sacerdote P (2002) The analgesic drug tramadol prevents the effect of surgery on natural killer cell activity and metastatic colonization in rats. J Neuroimmunol 129: 18-24.

Glattard E, Welters ID, Lavaux T, Muller AH, Laux A, Zhang D, Schmidt AR, Delalande F, Laventie BJ, Dirrig-Grosch S, Colin DA, Van Dorsselaer A, Aunis D, Metz-Boutigue MH, Schneider F, Goumon Y (2010) Endogenous morphine levels are increased in sepsis: a partial implication of neutrophils. PLoS One 5: e8791.

Hashiguchi S, Morisaki H, Kotake Y, Takeda J (2005) Effects of morphine and its metabolites on immune function in advanced cancer patients. J Clin Anesth 17: 575-580.

Heaney A, Buggy DJ (2012) Can anaesthetic and analgesic techniques affect cancer recurrence or metastasis? Br J Anaesth 109(Suppl 1): i17-i28.

House RV, Thomas PT, Bhargava HN (1995) In vitro evaluation of fentanyl and meperidine for immunomodulatory activity. Immunol Lett 46: 117-124.

Hutchinson MR, Coats BD, Lewis SS, Zhang Y, Sprunger DB, Rezvani N, Baker EM, Jekich BM, Wieseler JL, Somogyi AA, Martin D, Poole S, Judd CM, Maier SF, Watkins LR (2008) Proinflammatory cytokines oppose opioid-induced acute and chronic analgesia. Brain Behav Immun. 22: $1178-1189$.

Hutchinson MR, Zhang Y, Shridhar M, Evans JH, Buchanan MM, Zhao TX, Slivka PF, Coats BD, Rezvani N, Wieseler J, Hughes TS, Landgraf KE, Chan S, Fong S, Phipps S, Falke JJ, Leinwand LA, Maier SF, Yin H, Rice KC, Watkins LR (2010) Evidence that opioids may have toll-like receptor 4 and MD-2 effects. Brain Behav Immun 24: 83-95.

Irwin M, Hauger RL, Brown M, Britton KT (1988) CRF activates autonomic nervous system and reduces natural killer cytotoxicity. Am J Physiol 255: R744-R747.

Jacobs R, Karst M, Scheinichen D, Bevilacqua C, Schneider U, Heine J, Schedlowski M, Schmidt RE (1999) Effects of fentanyl on cellular immune functions in man. Int J Immunopharmacol 21: 445-454.

Keiser MJ, Setola V, Irwin JJ, Laggner C, Abbas AI, Hufeisen SJ, Jensen NH, Kuijer MB, Matos RC, Tran TB, Whaley R, Glennon RA, Hert J, 
Thomas KL, Edwards DD, Shoichet BK, Roth BL (2009) Predicting new molecular targets for known drugs. Nature 462: 175-181.

Kelly E, Bailey CP, Henderson G (2008) Agonist-selective mechanisms of GPCR desensitization. Br J Pharmacol 153(Suppl 1): S379-S388.

Makimura C, Arao T, Matsuoka H, Takeda M, Kiyota H, Tsurutani J, Fujita Y, Matsumoto K, Kimura H, Otsuka M, Koyama A, Imamura CK, Yamanaka T, Tanaka K, Nishio K, Nakagawa K (2011) Prospective study evaluating the plasma concentrations of twenty-six cytokines and response to morphine treatment in cancer patients. Anticancer Res 31: 4561-4568.

Martucci C, Panerai AE, Sacerdote P (2004) Chronic fentanyl or buprenorphine infusion in the mouse: similar analgesic profile but different effects on immune responses. Pain 110: 385-392.

Mellon RD, Bayer BM (1998) Role of central opioid receptor subtypes in morphine-induced alterations in peripheral lymphocyte activity. Brain Res 789: 56-67.

Moher D, Liberati A, Tetzlaff J, Altman DG, Group P (2009) Preferred reporting items for systematic reviews and meta-analyses: the PRISMA statement. PLoS Med 6: e1000097.

Molitor TW, Murtaugh MP, Click RE, Gekker G, Chao C, Peterson PK (1992) Functional alterations of swine peripheral blood mononuclear cells by methadone. J Leukoc Biol 51: 124-128.

Morton LM, Dores GM, Tucker MA, Kim CJ, Onel K, Gilbert ES, Fraumeni Jr JF, Curtis RE (2013) Evolving risk of therapy-related acute myeloid leukemia following cancer chemotherapy among adults in the United States, 1975-2008. Blood 121: 2996-3004.

Nüssler NC, Stange BJ, Petzold M, Nussler AK, Glanemann M, Guckelberger O (2007) Reduced NK-cell activity in patients with metastatic colon cancer. EXCLI J 6: 1-9.

Page GG (2003) The immune-suppressive effects of pain. Adv Exp Med Biol 521: $117-125$.

Page GG (2005) Immunologic effects of opioids in the presence or absence of pain. J Pain Symptom Manage 29: S25-S31.

Page GG, Blakely WP, Ben-Eliyahu S (2001) Evidence that postoperative pain is a mediator of the tumor-promoting effects of surgery in rats. Pain $\mathbf{9 0}$ 191-199.

Pages F, Kirilovsky A, Mlecnik B, Asslaber M, Tosolini M, Bindea G, Lagorce C, Wind P, Marliot F, Bruneval P, Zatloukal K, Trajanoski Z, Berger A, Fridman WH, Galon J (2009) In situ cytotoxic and memory $\mathrm{T}$ cells predict outcome in patients with early-stage colorectal cancer. J Clin Oncol 27: 5944-5951.

Palm S, Lehzen S, Mignat C, Steinmann J, Leimenstoll G, Maier C (1998) Does prolonged oral treatment with sustained-release morphine tablets influence immune function? Anesth Analg 86: 166-172.

Pergolizzi J, Boger RH, Budd K, Dahan A, Erdine S, Hans G, Kress HG, Langford R, Likar R, Raffa RB, Sacerdote P (2008) Opioids and the management of chronic severe pain in the elderly: consensus statement of an International Expert Panel with focus on the six clinically most often used World Health Organization step III opioids (buprenorphine, fentanyl, hydromorphone, methadone, morphine, oxycodone). Pain Pract 8: $287-313$.

Provinciali M, Di Stefano G, Raffaeli W, Pari G, Desiderio F, Fabris N (1991) Evaluation of NK and LAK cell activities in neoplastic patients during treatment with morphine. Int J Neurosci 59: 127-133.

Provinciali M, Di Stefano G, Stronati S, Raffaeli W, Pari G, Fabris N (1996) Role of prolactin in the modulation of NK and LAK cell activity after short- or long-term morphine administration in neoplastic patients. Int J Immunopharmacol 18: 577-586.

Reiman JM, Kmieciak M, Manjili MH, Knutson KL (2007) Tumor immunoediting and immunosculpting pathways to cancer progression. Semin Cancer Biol 17: 275-287.

Sacerdote P (2008) Opioid-induced immunosuppression. Curr Opin Support Palliat Care 2: 14-18.

Sacerdote P, Bianchi M, Gaspani L, Manfredi B, Maucione A, Terno G, Ammatuna M, Panerai AE (2000) The effects of tramadol and morphine on immune responses and pain after surgery in cancer patients. Anesth Analg 90: 1411-1414.

Sacerdote P, Manfredi B, Mantegazza P, Panerai AE (1997) Antinociceptive and immunosuppressive effects of opiate drugs: a structure-related activity study. Br J Pharmacol 121: 834-840.

Saurer TB, Ijames SG, Lysle DT (2006) Neuropeptide Y Y1 receptors mediate morphine-induced reductions of natural killer cell activity. J Neuroimmunol 177: 18-26.

Shavit Y, Ben-Eliyahu S, Zeidel A, Beilin B (2004) Effects of fentanyl on natural killer cell activity and on resistance to tumor metastasis in rats. Dose and timing study. Neuroimmunomodulation 11: 255-260.

Snyder GL, Greenberg S (2010) Effect of anaesthetic technique and other perioperative factors on cancer recurrence. Br J Anaesth 105: $106-115$.

Stefano GB, Kream RM, Mantione KJ, Sheehan M, Cadet P, Zhu W, Bilfinger TV, Esch T (2008) Endogenous morphine/nitric oxide-coupled regulation of cellular physiology and gene expression: implications for cancer biology. Semin Cancer Biol 18: 199-210.

Stein C, Lang LJ (2009) Peripheral mechanisms of opioid analgesia. Curr Opin Pharmacol 9: 3-8.

Terpos E, Berenson J, Raje N, Roodman GD (2014) Management of bone disease in multiple myeloma. Expert Rev Hematol 7: 113-125.

Thomas PT, House RV, Bhargava HN (1995) Direct cellular immunomodulation produced by diacetylmorphine (heroin) or methadone. Gen Pharmacol 26: 123-130.

Van Der Laan JW, Timmerman H, Van Loveren H (1996) Comparison of the in vivo effects of morphine and methadone on natural killer cell activity in spleen, peritoneal cavity, and lungs in rats. Int J Immunopharmacol 18: 401-407.

Van Leeuwen MT, Webster AC, Mccredie MR, Stewart JH, Mcdonald SP, Amin J, Kaldor JM, Chapman JR, Vajdic CM, Grulich AE (2010) Effect of reduced immunosuppression after kidney transplant failure on risk of cancer: population based retrospective cohort study. BMJ 340: $c 570$.

Wang J, Charboneau R, Balasubramanian S, Barke RA, Loh HH, Roy S (2002) The immunosuppressive effects of chronic morphine treatment are partially dependent on corticosterone and mediated by the mu-opioid receptor. J Leukoc Biol 71: 782-790.

West JP, Lysle DT, Dykstra LA (1997) Tolerance development to morphine-induced alterations of immune status. Drug Alcohol Depend 46: 147-157.

Whiting PF, Rutjes AW, Westwood ME, Mallett S, Deeks JJ, Reitsma JB, Leeflang MM, Sterne JA, Bossuyt PM. Group, Q. (2011) QUADAS-2: a revised tool for the quality assessment of diagnostic accuracy studies. Ann Intern Med 155: 529-536.

Williams JP, Thompson JP, Mcdonald J, Barnes TA, Cote T, Rowbotham DJ, Lambert DG (2007) Human peripheral blood mononuclear cells express nociceptin/orphanin $\mathrm{FQ}$, but not mu, delta, or kappa opioid receptors. Anesth Analg 105: 998-1005.

Yeager MP, Colacchio TA, Yu CT, Hildebrandt L, Howell AL, Weiss J, Guyre PM (1995) Morphine inhibits spontaneous and cytokine-enhanced natural killer cell cytotoxicity in volunteers. Anesthesiology 83: 500-508.

Yeager MP, Procopio MA, Deleo JA, Arruda JL, Hildebrandt L, Howell AL (2002) Intravenous fentanyl increases natural killer cell cytotoxicity and circulating CD16(+) lymphocytes in humans. Anesth Analg 94: 94-99.

Yeager MP, Yu CT, Campbell AS, Moschella M, Guyre PM (1992) Effect of morphine and beta-endorphin on human $\mathrm{FC}_{\mathrm{C}}$ receptor-dependent and natural killer cell functions. Clin Immunol Immunopathol 62: 336-343.

This work is published under the standard license to publish agreement. After 12 months the work will become freely available and the license terms will switch to a Creative Commons AttributionNonCommercial-Share Alike 3.0 Unported License. 